\title{
Kt-Thullsh $\mathbf{b}$ b
}

PENGARUH PENDEKATAN KONTEKSTUAL DENGAN STRATEGI REACT TERHADAP HASIL BELAJAR KOGNITIF MATERI BANGUN RUANG PADA SISWA KELAS V SDN 1 GONDANG

\author{
Dwi Cahyani ${ }^{1}$, Rohmatus Syafi'ah ${ }^{2}$ \\ ${ }^{1,2}$ STKIP PGRI Tulungagung \\ e-mail: ${ }^{1}$ dwi.cahyani260@ gmail.com, ${ }^{2}$ syafiahzainul@gmail.com
}

\begin{abstract}
The lack of the cognitive learning on the material of building is background of this research. It is proved of almost students that getting of lower score in criteria completeness of minimum (KKM). One of alternative solution from this problem is apply of contextual approach with REACT strategy. The purpose of this research to describe there is any influence between contextual approach and REACT strategy for the result of lesson special on building material. This research is quantitative research design with quasi experimental. The research show that there is any influence between contextual approach and REACT strategy for the cognitive learning. The analysis of data $t$-test show that score Sig.(2-tailed) $<0,05$ is $0,000<0,05$.
\end{abstract}

Keywords: contextual approach, react strategy, cognitive learning, building space

\section{A. Pendahuluan}

Pada dasarnya setiap manusia telah memiliki berbagai potensi dalam dirinya. Potensi tersebut berupa akal dan pikiran yang membedakan manusia dengan mahkluk lainnya. Setiap potensi yang dimiliki manusia dapat berkembang dengan baik apabila melalui proses pendidikan. Seperti yang termuat dalam undang-undang sistem pendidikan nasional No. 20 Tahun 2003 pasal 1 yang menyatakan bahwa : Pendidikan merupakan suatu usaha sadar yang terencana demi terciptanya suasana belajar dan proses pembelajaran agar peserta didik secara aktif mengembangkan potensi yang telah dimilikinya untuk mendapatkan kekuatan spiritual, keagamaan, pengendalian diri, kepribadian, kecerdasan, akhlak mulia, serta ketrampilan yang dibutuhkan oleh dirinya, masyarakat, bangsa, dan negara.

Suasana belajar dan proses pembelajaran sangat mempengaruhi prestasi belajar siswa. Penerapan kurikulum 2013 menuntut siswa untuk aktif dan kreatif. Kurikulum 2013 di SD diterapkan pada semua mata pelajaran termasuk pelajaran matematika. (Amir, 2014) Menyatakan bahwa pembelajaran matematika di Sekolah Dasar berbeda dengan pembelajaran matematika di SMP dan SMA. Karakteristik matematika SD menuntut adanya pemberian konsep dari hal-hal yang sederhana menuju ke hal yang lebih sulit atau rumit dengan memanfaatkan benda-benda konkrit atau riil yang ada disekitar siswa. 
Berdasarkan hasil observasi yang peneliti lakukan di SDN 1 Gondang ternyata masih banyak siswa dari kakak kelas sebelumnya yang memperoleh nilai di bawah batas Kriteria Ketuntasan Minimal (KKM) pada materi bangun ruang. Penyebab dari banyaknya siswa yang mendapat nilai di bawah KKM pada materi bangun ruang yaitu belum optimalnya penggunaan benda-benda konkret yang ada disekitar siswa untuk membantu memahami konsep-konsep pada materi bangun ruang. Ketidakmampuan siswa dalam memahami konsep bangun ruang inilah yang akhirnya berpengaruh terhadap prestasi akademik mereka. Guru kurang melibatkan keakifan siswa secara optimal dalam proses pembelajaran. Siswa hanya diberikan pengetahuan tentang bangun ruang secara abstrak, tanpa diperlihatkan benda-bendanya secara konkret. Setelah guru selesai memberikan penjelasan tentang materi, siswa disuruh untuk mengerjakan soalsoal yang terdapat pada buku. Proses pembelajaran seperti ini sebenarnya sangat bertentangan dengan teori perkembangan Piaget yang menyatakan bahwa pada usia 612 tahun anak berada pada tahap konkrit (Ibda, 2015).

Berkaitan dengan permasalahan tersebut perlu adanya suatu pembaharuan dalam proses pembelajaran di dalam kelas yaitu dengan menempatkan siswa sebagai subjek belajar sekaligus objek belajar. Salah satu pendekatan dan strategi pembelajaran yang mampu melibatkan keaktifan siswa yaitu pendekatan konstesktual dengan strategi REACT, karena strategi dan pendekatan ini mampu mengaitkan apa yang dipelajari siswa di sekolah dengan pengalamannya sendiri di kehidupan nyata dan kejadiankejadian yang ada dirumah mereka. REACT merupakan salah satu strategi dalam pembelajaraan kontekstual.

Pembelajaran kontekstual (Contextual Teaching and Laerning) adalah konsep belajar yang membantu guru mengaitkan antara materi yang diajarkannya dengan situasi dunia nyata siswa serta mendorong siswa membuat hubungan antara pengetahuan yang dimilikinya dengan penerapannya dalam kehidupan mereka sehari-hari, dengan melibatkan tujuh komponen utama pembelajaran afektif yaitu konstruktivisme (contructivism), bertanya (questioning), menemukan (inquiri), masyarakat belajar (learning community), pemodelan (modeling), refleksi dan penilaian sebenarnya (authentic assessment) (Shoimin, 2014).

Penggunaan pendekatan kontekstual berstrategi REACT ini menjadikan proses pembelajaran lebih menyenangkan, semua materi yang disajikan oleh guru sangat konkrit dan ada di kehidupan siwa sehari-hari. Siswa diberi kesempatan untuk membangun konsep sendiri dengan cara pembelajaran berkelompok. Siswa akan belajar bekerja sama, memperkaya pengetahuan, serta melatih rasa percaya diri dalam menyampaikan pendapat kepada teman. Pernyataan tersebut didukung oleh pendapat Husna (2014) dalam Jaliah, Irawati, dan Sujana (2017) yang menyatakan bahwa pembelajaran dengan strategi REACT menumbuhkan siswa untuk mengkontruksi 
pengetahuannya sendiri, sehingga peran siswa dalam pembelajaran cenderung aktif dan tidak pasif serta pembelajarn tidak terfokus pada kegiatan menghafal rumus-rumus yang diajarkan oleh guru. Namun lebih terfokus kepada pembelajaran bermakna. Strategi REACT merupakan salah satu strategi yang cocok dipadukan dengan pendekatan kontekstual mengingat kedua komponen pembelajaran ini mampu menghadirkan dunia nyata ke dalam kelas dan mendorong siswa membuat hubungan antara pengetahuan yang dimiliki dengan penerapan dalam kehidupan sehari-hari. Langkah-langkah pembelajaran menggunakan strategi REACT dalam (Arifin, 2014) yaitu, Relating (menghubungkan), Experiencing (mengalami), Applying (mengaplikasikan), Cooperating (bekerja sama), Transfering (memindahkan). Pemilihan strategi pembelajaran yang tepat dapat membantu guru dalam menciptakan suasana kelas lebih aktif dan tidak terkesan monoton, oleh karena itu guru harus mampu menempatkan diri dalam suatu proses pembelajaran baik sebagai fasilitator maupun mediator.

Mata pelajaran matematika pada materi bangun ruang yang ada di kelas $\mathrm{V}$ sangat relevan apabila menggunakan pendekatan kontekstual. Apalagi dengan beberapa kelebihan yang dimiliki pendekatan kontekstual seperti: (1) pembelajaran kontekstual mampu menekankan aktivitas berpikir siswa secara penuh, baik fisik maupun mental, (2) Pembelajaran konteksual dapat menjadikan siswa belajar tidak dengan menghafal, melainkan proses berpengalaman dalam kehidupan nyata, (3) Kelas dalam kontekstual tidak lagi sebagi tempat untuk memperoleh informasi, melainkan sebagai tempat untuk menguji data hasil temuan mereka di lapangan, (4) Materi pelajaran ditentukan oleh siswa sendiri, bukan hasil pemberian dari orang lain (Sofan, 2010).

Hal ini terdapat kesesuaian antara sifat-sifat CTL dengan karakteristik mata pelajaran matematika apalagi didukung dengan penggunaan strategi $R E A C T$, yang mana strategi ini sangat menitikberatkan pada keaktifan dan partisipasi dari peserta didik yang belajar. Sifat yang dimaksud adalah bahwa CTL mengaitkan isi mata pelajaran dengan dunia nyata dan memotivasi siswa membuat hubungan antara pengetahuan dan penerapannya dalam kehidupan mereka sendiri. Pada materi bangun ruang siswa akan belajar melakukan pengukuran melalui benda atau objek nyata yang ada disekitar mereka, penggunaan pendekatan kontekstual dengan strategi REACT ini diharapkan mampu meningkatkan hasil belajar siswa utamanya dalam pelajaran matematika.

Hasil belajar siswa adalah gambaran kemampuan siswa yang diperoleh dari hasil penilaian proses belajar siswa dalam mencapai tujuan pengajaran. Hasil belajar terdiri dari aspek kognitif, aspek psikomotorik dan aspek afektif. (Anderson dkk, 2010) dalam (Nurmisanti et al, 2017) menyatakan bahwa hasil belajar ranah kognitif terdiri dari aspek mengingat, memahami, menerapkan, menganalisis, mengevaluasi dan mencipta.

Oleh karenanya, berdasarkan uraian dan latar belakang yang telah dikemukakan di atas, penulis menganggap bahwa permasalahan ini penting untuk dicari solusinya. 
Maka dari itu penulis melakukan penelitian yang bertujuan untuk mengetahui pengaruh pendekatan kontekstual dengan strategi REACT terhadap hasil belajar kognitif materi bangun ruang pada siswa kelas V SDN 1 Gondang.

\section{B. Metode}

\section{Jenis Penelitian}

Penelitian ini dilakukan untuk mengatahui adanya hubungan sebab-akibat antara variabel bebas dengan variabel terikat, sehingga bisa disimpulkan bahwa penelitian ini termasuk kedalam penelitian eksperimen dengan desain quasi ekperimen karena pemilihan sampel dilakukan secara sengaja. Menurut Sugiyono penelitian eksperimen adalah penelitian yang digunakan untuk mencari pengaruh perlakukan tertentu terhadap yang lain dalam kondisi yang terkendalikan (Sugiyono, 2015). Metode pengambilan data berupa pretest dan posttest untuk mengetahui adanya perbedaan hasil pretest dan posttest sebelum dan sesudah diberikan perlakuan.

\section{Instrumen Penelitian}

Menurut Sugiyono instrumen penelitian adalah suatu alat yang digunakan mengukur fenomena alam maupun sosial yang diamati. Instrumen pengumpulan data yang digunakan dalam penelitian ini adalah sebagai berikut (Sugiyono, 2015):

a. Dokumentasi

Pedoman dokumentasi adalah daftar yang berisikan patokan-patokan dalam menelusuri panduan. Alat bantu yang digunakan peneliti untuk mengumpulkan datadata tertulis yang akan menjadi sampel, nilai siswa, foto-foto, buku-buku yang relevan, dan laporan kegiatan selama proses penelitian.

b. Lembar observasi

Lembar observasi digunakan untuk mengukur keterlaksanaan perencanaan pembelajaran menggunakan pendekatan dan strategi yang telah ditentukan. Langkahlangkah pada rencana pelaksanaan pembelajaran (RPP) mampu dijadikan sebagai tolok ukur dari keterlaksanaan proses pembelajaran. Lembar observasi diberikan kepada observer dalam hal ini yaitu guru kelas.

c. Tes

Lembar tes yang diberikan berupa tes tulis obyektif berbentuk pilihan ganda berjumlah 20 soal dengan 4 pilihan jawaban. Penyusunan soal tes berdasarkan pada tujuan pembelajaran yang hendak dicapai dengan memperimbangkan taksonomi Bloom. Bentuk pilihan ganda dipilih peneliti karena sistem penilaian mudah, cepat cara pemeriksaannya, dan tidak ada unsur subyekif yang mempengaruhi dalam pemeriksaan. Menurut (Usaman dan Setiawati, 2001) dalam (Rahman, Fuadi \& Maslianti, 2015) cara penghitungan nilai akhir dengan membandingkan total nilai skor maksimal yang diperoleh siswa kemudian dikalikan 100 dengan rumus : 


$$
\mathrm{N}=\frac{\text { Skor perolehan }}{\text { Skor maksimal }} \times 100 \longrightarrow \mathrm{N}=\text { Nilai akhir }
$$

\section{Tempat dan Waktu Penelitian}

a. Tempat

Penelitian ini dilaksanakan di jenjang Sekolah Dasar yaitu SDN 1 Gondang yang berlokasi di Kecamatan Gondang Kabupaten Tulungagung.

b. Waktu Penelitian

Penelitian ini dilaksanakan pada bulan April sampai Mei tahun 2019.

\section{Teknik Pengujian Instrumen}

a. Uji Validitas

Pada penelitian ini, peneliti menggunakan instrumen lembar observasi dan tes hasil belajar. Kedua instrumen tersebut perlu diuji validitasnya untuk mengetahui tingkat kesahihannya. Sebelum instrumen tes dan lembar observasi digunakan, instrumen tersebut harus dikonsultasikan kepada ahli yaitu dosen. Setelah intrumen tes mendapat persetujuan dari ahli, maka peneliti bisa mengujicobakan tes tersebut pada sekolah lain atau kelompok kecil siswa yang memiliki kemampuan hampir sama.

b. Taraf Kesukaran Soal

Taraf kesukaran soal adalah peluang untuk menjawab benar suatu soal pada tingkat kemampuan tertentu yang biasa dinyatakan dengan indeks. Indeks ini biasa dinyatakan dengan proporsi yang dinyatakan dengan proporsi yang besarnya antara 0,00 sampai dengan 1,00 semakin besar tingkat kesukaran bearti soal semakin mudah. Rumus yang digunakan untuk mencari taraf kesukaran soal, yaitu

$$
\text { Tingkat kesukaran }=\frac{\text { jumlah siswa yang men jawab benar }}{\text { jumlah siswa yang mengikuti tes }}
$$

Menurut (K. E. Lestari \& Yudhanegara, 2015) interpretasi indeks kesukaran suatu butir soal adalah sebagai berikut :

Tabel 1. Kriteria Indeks Kesukaran Instrumen

\begin{tabular}{cc}
\hline Indeks Kesukaran (IK) & Interpretasi Indeks Kesukaran \\
\hline $\mathrm{IK}=0,00$ & Terlalu sukar \\
\hline $0,00<\mathrm{IK} \leq 0,03$ & Sukar \\
\hline $0,30<\mathrm{IK} \leq 0,70$ & Sedang \\
\hline $0,70<\mathrm{IK}<1,00$ & Mudah \\
\hline $\mathrm{IK}=1,00$ & Terlalu mudah \\
\hline
\end{tabular}


c. Daya Pembeda

Menurut (Arikunto, 2006) dalam (Solichin, 2017) Daya pembeda soal adalah kemampuan sesuatu soal untuk membedakan antara siswa yang pandai (berkemampuan tinggi) dengan siswa yang kurang pintar (berkemampuan rendah).

5. Kriteria Pengukuran

Menurut (Prastowo, 2011) kriteria penskoran meliputi :

a) Nilai 91-100 berarti amat baik

b) Nilai 71-90 berarti baik

c) Nilai 61 berarti cukup

d) Nilai kurang dari 60 berarti kurang

6. Analisis Data

1. Keterlaksanaan Pembelajaran

Presentase ketelaksanaan pembelajaran dihitung menggunakan rumus sebagai berikut :

$$
\% \mathrm{KP}=\frac{\text { Banyaknya lagkah pembelajaran yang terlaksana }}{\text { Banyaknya langkah pembelajaran dalam } R P P} \mathrm{X} 100 \%
$$

Aturan penentuan kriteria level (Ratumanan, G., \& Laurent, 2011) diperoleh:

$\% \mathrm{KP}$ maksimal $=100 \%$

$\% \mathrm{KP}$ minimal $=0 \%$

Sehingga mediannya adalah 50\% dan pengkategoriannya adalah:

$0 \%<\mathrm{KP} \leq 25 \%$ Pembelajaran dikatakan terlaksana dengan tidak baik

$25 \%<\mathrm{KP} \leq 50 \%$ Pembelajaran dikatakan terlaksana dengan kurang baik

$50 \%<\mathrm{KP} \leq 75 \%$ Pembelajaran dikatakan terlaksana dengan baik

$75 \%<\mathrm{KP} \leq 100 \%$ Pembelajaran diakatakan terlaksana dengan sangat baik (Khabibah, 2006)

2. Uji Prasyarat

a. Uji Normalitas

Uji normalitas bertujuan untuk mengetahui sampel yang diambil dari populasi yang berdistribusi normal atau tidak.

b. Uji Homogenitas

Uji homogenitas dilakukan untuk mengetahui apakah varian data tes kelompok eksperimen (kelas A) sama dengan kelompok kontrol (kelas B).

c. Uji Hipotesis

Menurut (Sugiyono, 2017:177) menguji hipotesis komparatif berarti menguji parameter populasi yang berbentuk perbandingan. Dalam pengujian ini peneliti menggunakan komparasi dua sampel yang menggunakan statistik parametris bila datanya berbentuk interval atau ratio menggunakan t-test 


\section{Hasil dan Pembahasan}

Sebelum dilakukan penelitian di sekolah, peneliti terlebih dahulu mempersiapakan perangkat pembelajaran berupa RPP, instrumen tes, dan lembar observasi. Semua perangkat pembelajaran tersebut, harus divalidasi terlebih dahulu. Validasi dilakukan oleh orang ahli dalam hal ini dosen PGSD STKIP PGRI Tulungagung. Setelah RPP maupun instrumen tes telah dinyatakan valid oleh ahli, selanjutnya peneliti menguji cobakan seluruh item soal kepada 26 responden, dari 20 item soal yang dilakukan uji validitas ternyata semuanya valid. Berikut hasil pretest dan posttest kelas eksperimen dan kelas kontrol yang diperoleh peneliti ditunjukkan pada tabel dibawah ini:

Tabel 2. Hasil Nilai Pretest dan Nilai Posttest Kelas Kontrol

\begin{tabular}{|c|c|c|}
\hline Nama & Nilai Pretest & Nilai Posttest \\
\hline FK & 40 & 40 \\
\hline FFA & 35 & 60 \\
\hline MNR & 30 & 40 \\
\hline $\mathrm{PA}$ & 20 & 50 \\
\hline DNS & 30 & 35 \\
\hline FNA & 20 & 35 \\
\hline IRI & 60 & 65 \\
\hline MLD & 60 & 60 \\
\hline RND & 35 & 45 \\
\hline PKJ & 30 & 45 \\
\hline RAR & 55 & 75 \\
\hline RDA & 45 & 50 \\
\hline $\mathrm{RM}$ & 60 & 60 \\
\hline RH & 55 & 70 \\
\hline SDPW & 20 & 40 \\
\hline KYS & 50 & 55 \\
\hline $\mathrm{AD}$ & 45 & 60 \\
\hline DA & 55 & 65 \\
\hline AN & 60 & 55 \\
\hline
\end{tabular}


Tabel 3. Hasil Nilai Pretest dan Nilai Posttest Kelas Eksperimen

\begin{tabular}{|c|c|c|}
\hline Nama & Nilai Pretest & Nilai Posttest \\
\hline ADN & 55 & 75 \\
\hline ADA & 75 & 85 \\
\hline AR & 75 & 90 \\
\hline DP & 30 & 70 \\
\hline FSW & 65 & 85 \\
\hline IHI & 70 & 90 \\
\hline IA & 50 & 80 \\
\hline KN & 45 & 75 \\
\hline MOLR & 75 & 90 \\
\hline MBKD & 75 & 90 \\
\hline NK & 70 & 85 \\
\hline NTCK & 45 & 70 \\
\hline PDRN & 50 & 70 \\
\hline RZ & 45 & 70 \\
\hline $\mathrm{RM}$ & 45 & 75 \\
\hline RL & 40 & 50 \\
\hline VAR & 80 & 100 \\
\hline YPP & 60 & 75 \\
\hline KA & 45 & 70 \\
\hline $\mathrm{DA}$ & 40 & 80 \\
\hline $\mathrm{NF}$ & 50 & 85 \\
\hline
\end{tabular}

Berdasarkan tabel di atas dapat diketahui bahwa sebanyak 3 siswa dikelas kontrol memperoleh nilai pretest terendah yakni 20, sedangkan 4 siswa di kelas kontrol memperoleh nilai pretest tertinggi yaitu 60. Nilai rata-rata pretest kelas kontrol adalah 42,7.Terdapat 1 siswa dikelas kontrol yang memperoleh Nilai posttest terendah yaitu 20. Sedangkan sebanyak 1 siswa yang memperoleh nilai posttest tertinggi dikelas kontrol yaitu 75.Nilai rata-rata posttest kelas kontrol adalah 52,11. Sedangkan nilai KKM untuk pembelajaran matematika pada kelas $\mathrm{V}$ adalah 67 . Nilai rata-rata pretest dan posttest di kelas kontrol yang diperoleh siswa kurang mencapai nilai KKM.

Di kelas eksperimen sebanyak 3 siswa memperoleh nilai pretest terendah yaitu 40.Sedangakan terdapat 1 siswa di kelas eksperimen yang memperoleh nilai pretest tertinggi yaitu 80. Nilai rata-rata pretest kelas eksperimen adalah 56,90. Nilai posttest terendah di kelas kontrol dimiliki oleh 1 orang siswa dengan nilai 50. Sedangkan nilai posttest tertinggi di kelas eksperimen adalah 100 yang diperoleh 1 siswa. Nilai rata-rata dari posttest kelas eksperimen adalah 79,05. Sedangkan nilai nilai KKM untuk pembelajaran matematika pada kelas $\mathrm{V}$ adalah 67 . Nilai rata-rata pretest di kelas eksperimen kurang mencapai KKM, sedangkan nilai rata-rata posttest mencapai KKM. 
Berdasarkan uraian di atas dapat disimpulkan bahwa nilai rata-rata posttest kelas eksperimen lebih tinggi dari pada kelas kontrol, yaitu nilai rata-rata posttest kelas eksperimen 79,05 sedangkan nilai rata-rata posttest kelas kontrol 52,11. Nilai rata-rata posttest kelas eksperimen lebih tinggi karena dalam pembelajarannya menggunakan pendekatan kontekstual dengan strategi REACT. Adapun pembelajaran di kelas kontrol dilakukan secara konvensional, sehingga nilai rata-rata posttest kelas kontrol kurang mencapai KKM. Nilai rata-rata kelas kontrol dan kelas eksperimen, dapat disajikan dalam bentuk diagram sebagai berikut :

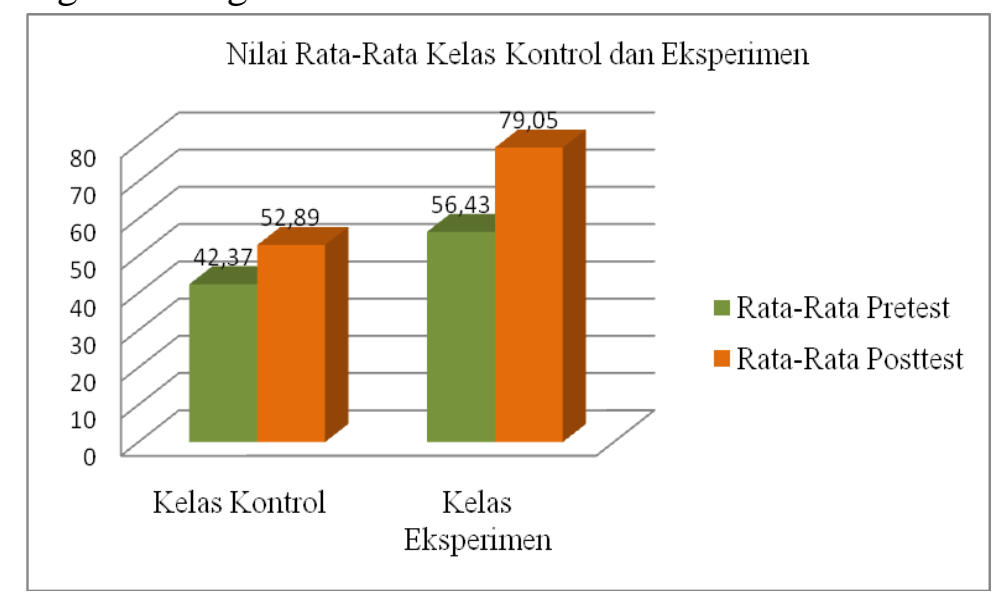

Diagram 1. Nilai Rata-Rata Kelas Kontrol dan Kelas Eksperimen

\section{Uji Prasyarat}

Syarat yang harus dipenuhi dalam menggunakan analisis varian adalah bahwa data berasal dari populasi yang berdistribusi normal dan kelompok-kelompok yang homogen. Oleh karena itu, peneliti terlebih dahulu harus melakukan pengujian berupa uji normalitas serta uji homogenitas agar peryaratan dalam analisis varian terpenuhi.

\section{a. Uji Normalitas}

Salah satu syarat yang harus dipenuhi dalam menggunakan analisis varian adalah bahwa data yang digunakan harus terdistribusi normal. Dalam penelitian ini uji normalitas dilakukan menggunakan uji statistik Kolmogrov-Smirnov dengan berbantuan program SPSS versi 16. Suatu data dikatakan terdistribusi normal apabila nilai Sig > 0,05. Sebaliknya jika nilai Sig $<0,05$ maka data tidak terdistribusi normal. Berdasarkan hasil uji normalitas menunjukkan bahwa pada kelas kontrol dan kelas eksperimen nilai Sig > 0,05 yaitu 0,613 > 0,05 untuk pretest kelas kontrol, 0,426 $<0,05$ untuk pretest kelas eksperimen, $0,818<0,05$ untuk posttest kelas kontrol, dan 0,687 $<0,05$ untuk posttest kelas eksperimen. Maka dengan demikian data yang digunakan dalam penelitian ini terdistribusi normal. Berikut keputusan dari hasil analisis uji normalitas tertuang dalam tabel 4. 
Tabel 4. Uji Normalitas

\begin{tabular}{|c|c|c|c|c|c|}
\hline \multicolumn{6}{|c|}{ One-Sample Kolmogorov-Smirnov Test } \\
\hline & & Pretest & Posttest & Pretest & Posttest \\
\hline & & Kelas & Kelas & Kelas & Kelas \\
\hline & & Kontrol & Kontrol & Eksperimen & Eksperimen \\
\hline \multicolumn{2}{|l|}{$\mathrm{N}$} & 19 & 19 & 21 & 21 \\
\hline \multirow{2}{*}{$\begin{array}{l}\text { Normal } \\
\text { Parameters }^{\mathrm{a}}\end{array}$} & Mean & 42.37 & 52.89 & 56.43 & 79.05 \\
\hline & Std. Deviation & 14.660 & 11.939 & 14.844 & 10.911 \\
\hline \multirow{3}{*}{$\begin{array}{l}\text { Most Extrem } \\
\text { Differences }\end{array}$} & Absolute & .174 & .145 & .191 & .156 \\
\hline & Positive & .116 & .123 & .191 & .121 \\
\hline & Negative & -.174 & -.145 & -.153 & -.156 \\
\hline \multicolumn{2}{|c|}{ Kolmogorov-Smirnov Z } & .758 & .633 & .877 & .714 \\
\hline \multicolumn{2}{|c|}{ Asymp. Sig. (2-tailed) } & .613 & .818 & .426 & .687 \\
\hline
\end{tabular}

Tabel 5. Keputusan Hasil Uji Normalitas

\begin{tabular}{llll}
\hline Keterangan & $\begin{array}{l}\text { Nilai Asymp. } \\
\text { Sig. (2-tailed) }\end{array}$ & $\begin{array}{l}\text { Taraf } \\
\text { Signifikansi }\end{array}$ & Keputusan \\
\hline Nilai Pretest Kelas Kontrol & 0,613 & 0,05 & Normal \\
\hline Nilai Posttest Kelas Kontrol & 0,818 & 0,05 & Normal \\
\hline Nilai Pretest Kelas Eksperimen & 0,426 & 0,05 & Normal \\
\hline Nilai Posttest Kelas Eksperimen & 0,687 & 0,05 & Normal \\
\hline
\end{tabular}

\section{b. Uji Homogenitas}

Uji homogenitas bertujuan untuk mengetahui apakah sampel berasal dari kelompok-kelompok yang homogen. Uji homogenitas dalam penelitian ini menggunakan One Way Anova dengan bantuan progran SPSS for windows versi 16. Apabila nilai signifikansi yang diperoleh $>0,05$ maka sampel berasal dari varians yang sama. Selanjutnya, apabila nilai signifikansi yang diperoleh $<0,05$ maka sampel berasal dari varians yang tidak sama. Adapun hasil uji homogenitas pada kelas kontrol dan kelas eksperimen sebagai berikut: 
Tabel 6. Data Hasil Uji Homogenitas

Test of Homogeneity of Variances
\begin{tabular}{llll}
\hline Skor_Pretest \\
\hline Levene Statistic & df1 & df2 & Sig. \\
\hline .020 & 1 & 38 & $\mathbf{. 8 8 8}$ \\
\hline
\end{tabular}

\begin{tabular}{|c|c|c|}
\hline Test of Homogeneity & aria & \\
\hline Skor_Posttest & & \\
\hline Levene Statistic df1 & df2 & Sig. \\
\hline .585 & 38 & .449 \\
\hline
\end{tabular}

\section{Uji Hipotesis}

Uji hipotesis dalam penelitian ini menggunakan uji t. Uji-t dilakukan dengan berbantuan program SPSS for windows version 16 dengan pilihan Independent Sample Test. Taraf signifikan yang digunakan adalah 5\% atau 0,05 dan df (degree of freedom) atau derajad kebebasannya $\mathrm{n}-\mathrm{k}$ (banyaknya responden - jumlah kelompok) yaitu 40-2 $=$ 38. Jika nilai Sig.(2-tailed) $<0,05$ dan nilai thitung $>\mathrm{t}_{\text {tabel }}$ maka $\mathrm{H}_{0}$ ditolak dan $\mathrm{H}_{\mathrm{a}}$ diterima. Adapun hasil uji-t dalam penelitian ini sebagai berikut :

\section{Tabel 7. Hasil Uji t}

\section{Independent Samples Test}

Levene's Test for Equality of Variances t-test for Equality of Means

\begin{tabular}{|c|c|c|c|c|c|c|c|c|c|c|}
\hline & & \multirow[b]{2}{*}{$\mathrm{F}$} & \multirow[b]{2}{*}{ Sig. } & \multirow[b]{2}{*}{$\mathrm{t}$} & \multirow[b]{2}{*}{$\mathrm{df}$} & \multirow{2}{*}{$\begin{array}{l}\text { Sig. } \\
(2- \\
\text { tailed) }\end{array}$} & \multirow{2}{*}{$\begin{array}{c}\text { Mean } \\
\text { Difference }\end{array}$} & \multirow{2}{*}{$\begin{array}{l}\text { Std. } \\
\text { Error } \\
\text { Diffe } \\
\text { rence }\end{array}$} & \multicolumn{2}{|c|}{$\begin{array}{l}95 \% \text { Confidence } \\
\text { Interval of the } \\
\text { Difference }\end{array}$} \\
\hline & & & & & & & & & Lower & Upper \\
\hline \multirow[t]{2}{*}{$\begin{array}{l}\text { Hasil } \\
\text { belajar }\end{array}$} & $\begin{array}{l}\text { Equal } \\
\text { variances } \\
\text { assumed }\end{array}$ & .585 & $.449^{\prime}$ & 7.239 & 38 & .000 & 26.153 & 3.613 & 18.840 & 33.466 \\
\hline & $\begin{array}{l}\text { Equal } \\
\text { variances } \\
\text { not } \\
\text { assumed }\end{array}$ & & & 7.206 & 36.648 & .000 & 26.153 & 3.629 & 18.797 & 33.509 \\
\hline
\end{tabular}


Dasar pengambilan keputusan :

1. Jika harga t hitung $<\mathrm{t}$ tabel, maka Ha ditolak

2. Jika harga $t$ hitung $>\mathrm{t}$ tabel, maka Ha diterima

3. Jika Sig (2-tailed) $<0,05$ maka Ha diterima

4. Jika Sig (2-tailed) $>0,05$ maka Ha ditolak

Berdasarkan tabel 6 di atas menunjukkan bahwa nilai Sig.(2-tailed) $<0,05$ yaitu $0,000<0,05$ dan nilai $t_{\text {hitung }}>t_{\text {tabel }}$ untuk taraf signifikansi 0,05 dengan df (derajad kebebasan) 38 adalah 2.0244. Sehingg nilai $t_{\text {hitung }}>t_{\text {tabel }}$ yaitu sebesar $7.239>2.0244$, dengan demikian $\mathrm{H}_{0}$ ditolak dan $\mathrm{H}_{\mathrm{a}}$ diterima.

\section{Simpulan}

Ada pengaruh pendekatan kontekstual dengan strategi REACT terhadap hasil belajar kognitif materi bangun ruang pada siswa kelas V SDN 1 Gondang. Hal ini dibuktikan dengan perolehan hasil uji t menunjukkan bahwa nilai Sig.(2-tailed) $<0,05$ yaitu $0,000<0,05$ dan nilai $t_{\text {hitung }}>\mathrm{t}_{\text {tabel }}$ untuk taraf signifikansi 0,05 dengan df (derajad kebebasan) 38 yaitu 2.0244. Sehingga nilai $t_{\text {hitung }}>t_{\text {tabel }}$ yaitu sebesar $7.239>2.0244$, dengan demikian $\mathrm{H}_{0}$ ditolak dan $\mathrm{H}_{\mathrm{a}}$ diterima.

\section{Daftar Rujukan}

Amir, A. (2014). Pembelajaran Matematika SD dengan Menggunakan Media $\begin{array}{llll}\text { Manipulatif. Forum } & \text { Paedagogik, } & \text { VI }(01), & \text { 72-89. }\end{array}$ https://doi.org/10.2214/AJR.10.5577

Arifin, A.T.; Karono; dan Sutarto, H. (2014). Keefektifan Strategi Pembelajaran React Pada Kemampuan Siswa Kelas VII Aspek Komunikasi Matematis. Kreano Jurnal, 5, 91-98.

Ibda, F. (2015). PERKEMBANGAN KOGNITIF : TEORI JEAN PIAGET, 3, 27-38.

Jaliah, R., Irawati, R., \& Sujana, A. (2017). Pengaruh Pendekatan Kontekstual Berstrategi Relating, Experiencing, Applying, Cooperating, Transferring ( React ), (20), 1091-1100.

K. E. Lestari \& Yudhanegara, M. R. (2015). Penelitian Pendidikan Matematika. Bandung: PT Refika Aditama.

Khabibah, S. (2006). Pengembangan Model Pembelajaran Matematika dengan Soal Terbuka untuk Meningkatkan Kreativitas Siswa Sekolah Dasar. Program Pascasarjana Unesa.

Nurmisanti. (2017). I DENTIFIKASI H ASIL B ELAJAR R ANAH K OGNITIF S ISWA P ADA M ATERI, 2(1), 17-18.

Prastowo, A. (2011). Menyusun Rancangan Pelaksanaan Pembelajaran (RPP) Tematik 
Terpadu Implementasi Kurikulum 2013 unutk SD/MI. Jakarta: Kencana.

Rahman, M. (2015). PENGARUH MODEL CREATIVE PROBLEM SOLVING ( CPS ) DALAM PEMBELAJARAN MATEMATIKA TERHADAP, 3(April), 67-74.

Ratumanan, G., \& Laurent, T. (2011). Penilaian Hasil Belajar pada Satuan Pendidikan edisi kedua. Bandung: Alfabeta.

Shoimin, A. (2014). 68 Model Pembelajaran Inovatif dalam Kurikulum 2013. Yogjakarta: Ar-Ruzz Media.

Sofan, A. \& I. K. A. (2010). Kontruksi Pengembangan Pembelajaran Pengaruhnya Terhadap Mekanisme dan Praktik Kurikulum. Jakarta: Prestasi Pustaka.

Solichin, M. (2017). ANALISIS DAYA BEDA SOAL, TARAF KESUKARAN, VALIDITAS BUTIR TES, INTERPRETASI HASIL TES DAN VALIDITAS RAMALAN DALAM EVALUASI PENDIDIKAN, 2, 192-213.

Sugiyono. (2015). Metode Penelitian Pendidikan (Pendekatan Kuantitatif, Kualitatif, dan $R \& D)$,. Bandung: Alfabeta. 